\title{
Analysis on Quality of Service at Design and Engineering Department by Using Servqual, IPA, and QFD Methods
}

\author{
Heru Indrawidjajanto and Bambang Syairudin \\ Department of Management Technology, Institut Teknologi Sepuluh Nopember (ITS), Surabaya \\ e-mail: heruindra@gmail.com
}

\begin{abstract}
PT. Semen Indonesia develops the cement business in Indonesia by striving to be at the forefront in the world of the cement manufacturing business, as well as trying to be a calculated player in the cement derivative business. To achieve this goal, the Department of Design \& Engineering, as a supporting function, always strives to provide the best service for customers, namely other work units within PT. Semen Indonesia group. There are 20 service attributes used as indicators in the questionnaire, covering five dimensions of service quality, namely tangible, empathy, responsiveness, reliability, and assurance. The measurement of the level of customer satisfaction of the Design \& Engineering Department is carried out by Service Quality (Servqual), Importance Performance Analysis (IPA), Quality Function Deployment (QFD) methods. The results show that based on Servqual analysis, in general, customers are still not satisfied with the resulting performance. Based on the results of the IPA analysis, five service attributes are the top priority for improvement, namely: coordination with customers, completion of Engineering work according to the agreed time, solutions to customer problems, able to meet customer needs, and product engineering by customer desires. Based on the results of the QFD analysis, there are six strategic steps in the work program carried out to improve service quality in the Design \& Engineering Department.
\end{abstract}

Keywords-Service Quality (Servqual), Importance Performance Analysis (IPA), Quality Function Deployment (QFD), Quality of Service.

\section{INTRODUCTION}

$\mathrm{I}_{\mathrm{e}}^{\mathrm{s}}$ N CONJUNCTION with the Indonesian population and economic growths, PT. Semen Indonesia (Persero) Tbk. serves as the government's medium to ensure the fulfillment of cement needs for infrastructure and building constructions in Indonesia. Semen Indonesia has four strategics to increase the volume of production capacity; those are constructing new plants, acquiring other cement factories, building new cement distribution facilities, and de-bottlenecking the existing cement factory facilities.

To apply those four strategics, Semen Indonesia assigns Engineering \& Project Directorate, particularly Design \& Engineering Department. This specific department plays an essential role in producing research, FEED (Front End Engineering Design), and DED (Detail Engineering Design).

The most complained problems are the long duration required to finish a product and the accuracy of the department's products. The Basic Design, which is the basis for estimating the budget and length of time of the project, contains errors that cause inaccuracy of budget calculation.

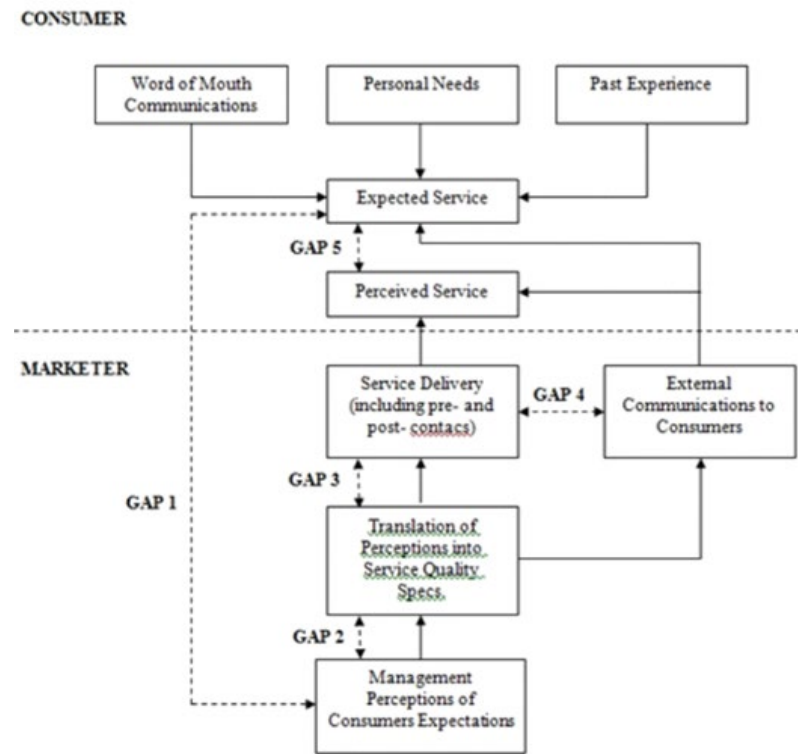

Figure 1. Servqual Method.

This prompts the long duration for procurement and dispute and postpones the project.

This study focuses on understanding the gap between the expectation and perception of the service received by internal customers. The gap is seen from various dimensions at Design \& Engineering Department: tangibles, empathy, reliability, responsiveness, and assurance. This research also aims at pointing out priority steps to overcome the problem.

The researcher hopes to contribute to improving the service quality of the department by identifying services requiring improvement and maintained to meet customer's satisfaction.

\section{METHOD}

\section{A. Service Quality (Servqual)}

Service Quality Analysis, also known as SERVQUAL, is a descriptional approach used to represent customer's satisfaction. This model was developed in 1985 by A. Parasuraman, Valarie A. Zeithaml, and Leonard L. Berry. Based on Parasuraman[1], Service Quality is defined as how far the gap between customer perception and expectation about the service they get. This method divides service quality into five dimensions, which are tangibles, empathy, reliability, responsive, and assurance.

Gap analysis is a method to compare customer's expectations and perceptions. This measurement is done by calculating the difference between attributes influencing the 
The $1^{\text {st }}$ International Conference on Business and Engineering Management (IConBEM 2020)

February $1^{\text {st }} 2020$, Institut Teknologi Sepuluh Nopember, Surabaya, Indonesia

Table 1.

Attribut Servqual from Pra-FGD

\begin{tabular}{|c|c|}
\hline Attribute & Description \\
\hline \multicolumn{2}{|r|}{ Tangible (TA) } \\
\hline TA.1 & Display Offices in Design \& Engineering \\
\hline TA.2 & Cleanliness of the Workspace in Design Engineering \\
\hline TA.3 & Hardware and Software tools in Design \& Engineering \\
\hline TA.4 & DE products have a structured display format. \\
\hline TA.5 & Visualization of the results of Design DE \\
\hline \multicolumn{2}{|r|}{ Emphaty (EM) } \\
\hline EM.1 & Employees are friendly and able to establish communication. \\
\hline EM.2 & Employees can provide assistance and assistance. \\
\hline EM.3 & Employees can meet the speed and quality of service. \\
\hline \multicolumn{2}{|r|}{ Responsiveness (RS) } \\
\hline RS.1 & Speed to coordinate with customers \\
\hline RS.2 & The convenience of DE employees to be contacted by \\
\hline RS.3 & Able to complete work according to customer wishes. \\
\hline RS.4 & Employees can provide solutions to problems. \\
\hline \multicolumn{2}{|r|}{ Reliability (RE) } \\
\hline RE.1 & Product Engineering is fulfill following the requirement \\
\hline RE.2 & Service Procedure Service is simple and straightforward \\
\hline RE.3 & Able to complete work, according to customer quality \\
\hline RE.4 & Integrity and professionalism at work \\
\hline \multicolumn{2}{|r|}{ Assurance (AS) } \\
\hline AS.1 & DE has Procedure, IK, and Standard Engineering. \\
\hline AS.2 & Employees can complete the design on time. \\
\hline AS.3 & Employees can guarantee the quality of the Design \\
\hline AS.4 & Employees have scientific and engineering skills. \\
\hline
\end{tabular}

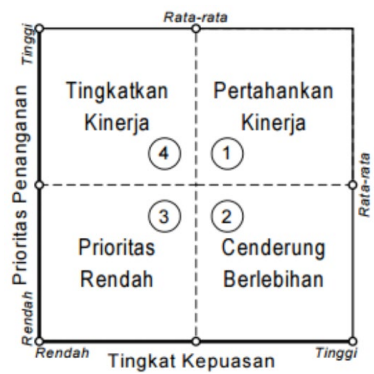

Figure 2. IPA Cartesian.

perception the customer has and their expectation about the service. The following formula can calculate the difference of customers satisfaction:

Service Quality $=$ Perception $(\mathrm{P})$ - Expectation $(\mathrm{E})$

According to the gap analysis equation, the result may become one of these following possibilities:

1. When the result is positive $(+)$, consumer perception exceeds the expectation. This implies that the company has good service quality in the eyes of the consumer.

2. If zero (0), the service quality meets the expectation.

3 . If the result is negative (-), the service quality of the company is lower than consumer expectation.

\section{B. Importance and Performance Analysis (IPA)}

Importance and Performance Analysis (IPA) instrument was firstly introduced by Martilla and James (1977) to measure customer satisfaction in the company's service or product. Based on the result of the instrument, the IPA Cartesian Diagram is divided into four quadrants as follows:

1. Quadrant I (Concentrate These): this quadrant implies that the indicator is considered important by the customer, but the company's performance is lower than customer expectations.

2. Quadrant II (Keep Up The Good Work): this area shows that the indicator of customer satisfaction is considered important, so that is should be maintained.
Table 2 .

Validity Test

\begin{tabular}{|c|c|c|c|c|c|c|c|c|}
\hline \multirow{2}{*}{$\begin{array}{c}\text { Attrib } \\
\text { ute }\end{array}$} & \multicolumn{5}{|c|}{ Perception } & \multicolumn{5}{c|}{ Expectation } \\
\cline { 2 - 10 } & Pearson & r count & r table & Status & Pearson & r count & r table & Status \\
\hline TA.1 & 0.61 & 6.27 & 1.67 & VALID & 0.51 & 4.89 & 1.67 & VALID \\
\hline TA.2 & 0.70 & 8.10 & 1.67 & VALID & 0.60 & 6.11 & 1.67 & VALID \\
\hline TA.3 & 0.78 & 10.36 & 1.67 & VALID & 0.76 & 9.75 & 1.67 & VALID \\
\hline TA.4 & 0.83 & 12.07 & 1.67 & VALID & 0.81 & 11.27 & 1.67 & VALID \\
\hline TA.5 & 0.78 & 10.39 & 1.67 & VALID & 0.68 & 7.71 & 1.67 & VALID \\
\hline EM.1 1 & 0.79 & 10.63 & 1.67 & VALID & 0.74 & 9.21 & 1.67 & VALID \\
\hline EM.2 & 0.80 & 10.99 & 1.67 & VALID & 0.80 & 11.03 & 1.67 & VALID \\
\hline EM.3 & 0.84 & 12.84 & 1.67 & VALID & 0.79 & 10.74 & 1.67 & VALID \\
\hline RS.1 & 0.78 & 10.34 & 1.67 & VALID & 0.78 & 10.30 & 1.67 & VALID \\
\hline RS.2 & 0.71 & 8.29 & 1.67 & VALID & 0.82 & 11.92 & 1.67 & VALID \\
\hline RS.3 3 & 0.89 & 15.78 & 1.67 & VALID & 0.88 & 15.51 & 1.67 & VALID \\
\hline RS.4 & 0.86 & 13.92 & 1.67 & VALID & 0.86 & 13.93 & 1.67 & VALID \\
\hline RE.1 1 & 0.88 & 15.14 & 1.67 & VALID & 0.81 & 11.39 & 1.67 & VALID \\
\hline RE.2 & 0.72 & 8.54 & 1.67 & VALID & 0.79 & 10.71 & 1.67 & VALID \\
\hline RE.3 & 0.80 & 10.84 & 1.67 & VALID & 0.82 & 11.72 & 1.67 & VALID \\
\hline RE.4 & 0.75 & 9.28 & 1.67 & VALID & 0.85 & 13.03 & 1.67 & VALID \\
\hline AS.1 1 & 0.70 & 8.06 & 1.67 & VALID & 0.82 & 11.81 & 1.67 & VALID \\
\hline AS.2 2 & 0.78 & 10.14 & 1.67 & VALID & 0.86 & 14.00 & 1.67 & VALID \\
\hline AS.3 3 & 0.87 & 14.23 & 1.67 & VALID & 0.87 & 14.31 & 1.67 & VALID \\
\hline AS.4 & 0.85 & 13.38 & 1.67 & VALID & 0.78 & 10.23 & 1.67 & VALID \\
\hline & & & & & & & & \\
\hline
\end{tabular}

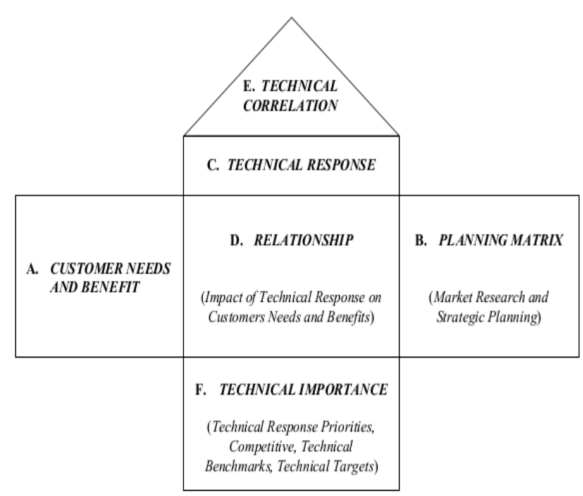

Figure 3. House of Quality.

3. Quadrant III (Low Priority): this quadrant indicates that the attribute is not considered important, and the performance is lower than customer expectations.

4. Quadrant IV (Possible Overkill): this quadrant shows that the attribute is less important, but the performance exceeds expectations.

\section{Quality Function Deployment (QFD)}

QFD is a method to engineer a structured product which allows the development team to determine customer expectations and needs, and evaluate the product or systematically provides service to meet customer satisfaction.

QFD is used to improve the company's understanding of the customer, as well as to develop its products, services, and processes focused on the customer. Matrix House of Quality (HoQ), or the house of quality, is the most popular representation of QFD. This matrix consists of two main parts. The first part is the horizontal section, also known as the customer table, which has any information related to the consumer. The second part, called a technical table, contains technical information as a response to the customer's table $[2]$.

HoQ is used by various industries to translate customer requirements, the result of market research, and data are benchmarking into several important technical targets. 
The $1^{\text {st }}$ International Conference on Business and Engineering Management (IConBEM 2020)

February $1^{\text {st }} 2020$, Institut Teknologi Sepuluh Nopember, Surabaya, Indonesia

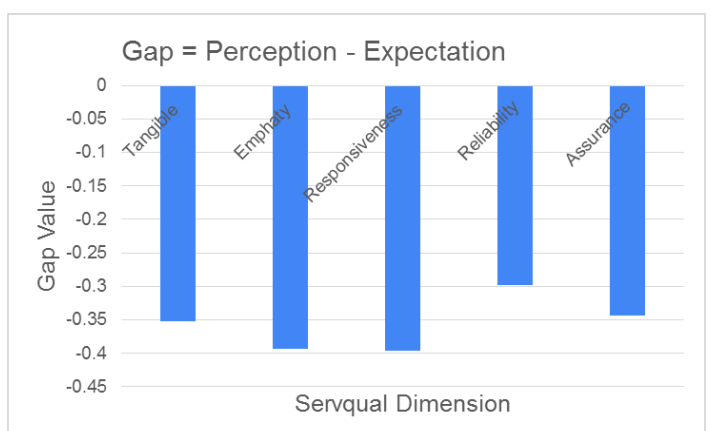

Figure 4. Gap=Perception - Expectation.

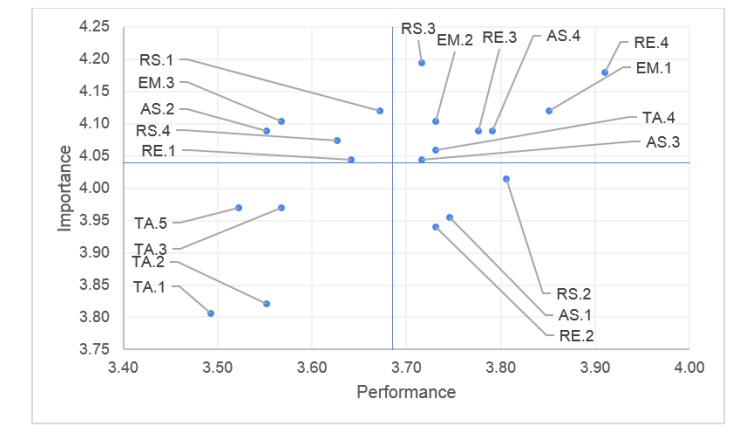

Figure 5. IPA Cartesian.

\section{RESULT AND DISCUSSION}

A structured questionnaire collects the data for this research. Attributes used in the survey are the attributes that resulted from Pre-FGD at Design \& Engineering Department. There are 20 questions, which represent 20 attributes in 5 dimensions of Servqual, as shown in Table 1.

There are 67 respondents of the research. Those respondents are the customers of Design \& Engineering Department from January until October 2019.

\section{A. Validity and Reliability Test}

The test is applied to learn the appropriateness of the questions in defining a variable. The validity coefficient is measured by Pearson product moment (r). R-count is matched with R-table significant level (r). If R-count is larger than 5\% $\mathrm{R}$-table, it means the questions are valid. Tables 2 show that the questions are valid.

The reliability test is used to determine the consistency of respondents' responses to the questions. The reliability test used in this research is Cronbach Alpha. The result is that the Cronbach Alpha value is as much as 0.93 for Perception Test and 0.93 for the Expectation Test. Since the Cronbach Alpha value is above 0.6, the result of the questionnaire is considered reliable.

\section{B. Servqual Analysis}

The researcher applies the Servqual model by calculating the Gap to separating attributes that have positive Gap from those that have negative Gap. The analysis results in showing that all attributes on the questionnaire have negative Gap towards the existing service quality attributes. In other words, Design \& Engineering Department is still far from satisfying the customers.
Table 3.

Attribut At Quadrant A

\begin{tabular}{|c|l|}
\hline Atribute & \multicolumn{1}{|c|}{ Attribute At Kuadran A } \\
\hline AS.2 & Employees can complete the design on time. \\
\hline EM3. & Employees can meet the speed and quality of service. \\
\hline RS.4 & Employees can provide solutions to problems. \\
\hline RE.1 & Product Engineering is fulfill following the requirement \\
\hline RS.1 & Speed to coordinate with customers \\
\hline
\end{tabular}

Based on the Servqual dimension, Empathy and Responsiveness have the most significant gaps, among other dimensions, as shown in Figure 4.

\section{Importance-Performance Analysis (IPA) Analysis}

Importance-Performance Analysis is used to measure customer satisfaction about the service provided and performance done, as well as to determine how far the company understands customer expectations about the service. This is done by determining coordinates for each existing attribute by using points resulted from Perception as the $\mathrm{x}$-axis and Expectation as the y-axis. Meanwhile, Center Point represents the average of all Perception and Expectation attributes.

IPA analysis of the Cartesian diagram for Quadrant A contains indicators that are considered significant by the customers, but the company's performance is lower than the customer's expectations. In this case, the company should pay more attention to improving these indicators. The result as shown in Figure 5 and Table 3.

\section{Quality Function Deployment (QFD) Analysis}

Quality Function Deployment (QFD) is a systematic approach to determine customer's expectations and to accurately translate the expectations into technical design and proper production planning. In essence, QFD assists the service provider to take notes on customer's expectations and to make sure that the expectations are included during a brainstorming session at the Development Team to fulfill customer's expectations.

The researcher uses the House of Quality to determine indicators that are influencing the level of service quality at Design \& Engineering Department. The improvement process mainly focuses on customer expectations, so that the design and development process can be in line with customer expectations.

1) Creating What's Customer Requirement Matrix.

The first step to create this HoQ is by listing top priority indicators in Quadrant A. These attributes serve as Voice of Customer (VOA) on What's Customer Requirement section. 2) Designing How Technical Response Matrix.

The second step is determining How Technical Response, how the management of the department takes improvement actions to fulfill customer expectations. The technical proposal for the improvement actions is carried out through Focus Group Discussion (FGD) among internal members of Design \& Engineering Department.

3) Relation between Matrix What and Matrix How.

This phase starts with identifying the relationship between Matrix What and Matrix How. Matrix What serves as the question and Matrix How the answer; this means that these matrices have a relationship. The following symbols show the value of the relationship between the Matrix: (Table 4) 
The $1^{\text {st }}$ International Conference on Business and Engineering Management (IConBEM 2020)

February $1^{\text {st }} 2020$, Institut Teknologi Sepuluh Nopember, Surabaya, Indonesia

Table 4.

Relation Matrix What dan How

\begin{tabular}{|c|c|c|c|c|c|c|c|c|c|c|}
\hline \multirow[b]{2}{*}{$\begin{array}{l}=\text { Strong, Hubungan Kuat, Nilai } 9 \\
=\text { Moderate, Hubungan Biasa, Nilai } 3 \\
=\text { Weak, Hubungan Lemah, Nilai } 1\end{array}$} & \multicolumn{10}{|c|}{ How's Technical Response } \\
\hline & 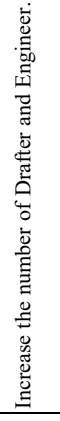 & 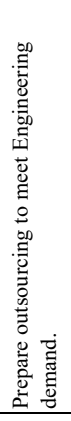 & 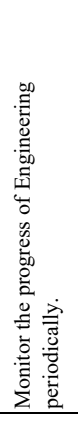 & 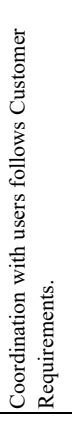 & 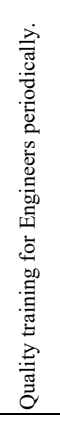 & 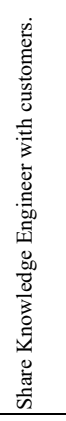 & 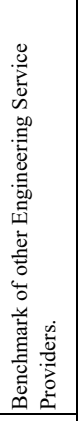 & 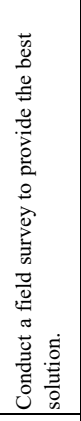 & 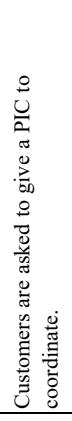 & 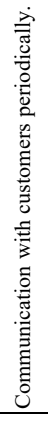 \\
\hline Speed to coordinate with customers & & & & $\nabla$ & $\mathrm{O}$ & $\nabla$ & $\nabla$ & D & $\nabla$ & $\bigcirc$ \\
\hline $\begin{array}{l}\text { Employees can meet the speed and } \\
\text { quality of service. }\end{array}$ & & & & $\nabla$ & $\bigcirc$ & $\nabla$ & $\nabla$ & ) & $\nabla$ & 0 \\
\hline $\begin{array}{l}\text { Employees can complete the design } \\
\text { on time. }\end{array}$ & $\nabla$ & $\nabla$ & & & & $\bigcirc$ & & $\Omega$ & $\bigcirc$ & \\
\hline $\begin{array}{l}\text { Employees can provide solutions to } \\
\text { problems. }\end{array}$ & & & & $\nabla$ & O & $\nabla$ & $\nabla$ & $\bigcirc$ & $\nabla$ & O \\
\hline $\begin{array}{l}\text { Product Engineering is fulfill following } \\
\text { the requirement }\end{array}$ & & & O & & 7 & $\nabla$ & $\nabla$ & & & \\
\hline
\end{tabular}

Table 5.

Relationship Between Technical Response

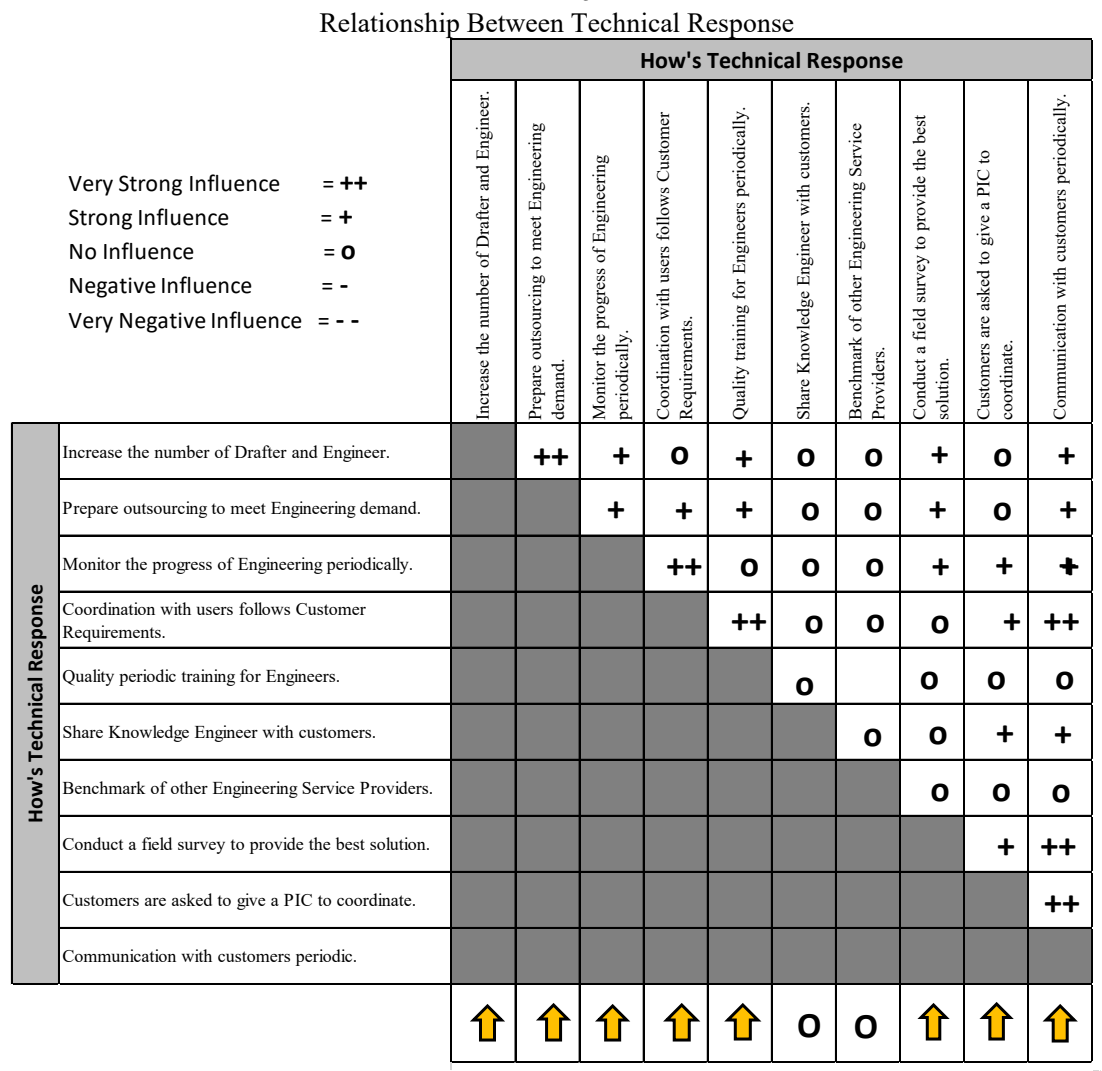

9: Very strong

3: Decent

1: Weak

4) Creating Relationship among How Technical Response.

The relationship between corrective actions in the technical response may reinforce each other or contradict each other. If the relationship among the improvement steps is mutually beneficial, the implementation will be admirable, and vice versa. If the relationship contradicts each other, it implies that the implementation should be reviewed, as shown Table 5. 5) Designing Prioritized Customer Requirement.

Prioritized Customer Requirement is a technique to set up a planning matrix that is used to translate customer expectations into a prioritized work program. The basis to make this matrix is data of customer expectations.

a. Perception Level (Customer Satisfaction Perfor-mance) 
The $1^{\text {st }}$ International Conference on Business and Engineering Management (IConBEM 2020)

February $1^{\text {st }} 2020$, Institut Teknologi Sepuluh Nopember, Surabaya, Indonesia

Table 6.

Prioritized Customer Requirement

\begin{tabular}{|l|c|c|c|c|c|c|}
\hline \multicolumn{1}{|c|}{ Services Attribute } & $\begin{array}{c}\text { Percep } \\
\text { tion }\end{array}$ & $\begin{array}{c}\text { Target } \\
\text { Value }\end{array}$ & IR & $\begin{array}{c}\text { Service } \\
\text { Point }\end{array}$ & $\begin{array}{c}\text { Normali } \\
\text { zed } \\
\text { Weight }\end{array}$ & $\begin{array}{c}\text { Prio- } \\
\text { rity }\end{array}$ \\
\hline $\begin{array}{l}\text { Employees can complete the } \\
\text { design on time. }\end{array}$ & 3.67 & 4.35 & 1.18 & 1.50 & 26.58 & 1 \\
\hline $\begin{array}{l}\text { Employees can meet the speed } \\
\text { and quality of service. }\end{array}$ & 3.57 & 4.00 & 1.12 & 1.00 & 16.30 & 4 \\
\hline $\begin{array}{l}\text { Employees can provide } \\
\text { solutions to problems. }\end{array}$ & 3.55 & 4.25 & 1.20 & 1.20 & 20.78 & 2 \\
\hline $\begin{array}{l}\text { Product Engineering is fulfill } \\
\text { following the requirement }\end{array}$ & 3.63 & 4.10 & 1.13 & 1.20 & 20.04 & 3 \\
\hline $\begin{array}{l}\text { Speed to coordinate with } \\
\text { customers }\end{array}$ & 3.64 & 4.00 & 1.10 & 1.00 & 16.30 & 5 \\
\hline
\end{tabular}

Customer Satisfaction Performance reflects custo-mer expectation level about the existing attributes. All result lies on Quadrant A.

b. Target Value

Target Value is a target of the level of improvement that needs to be achieved by the management, based on their improvement skills. Internal FGD is applied to determine the most feasible target value.

c. Determine the Improvement Ratio

Improvement Ratio is a comparison between the target value and customer satisfaction performance, or comparison between Performance Improvement Target and Customer Perception for each attribute.

d. Service Point.

Service Point is determined during the FGD. The value of this service point reflects the result achieved when the company improves the related attribute. The service point used in this research is defined as follows:

1: weak service quality

1.2: decent service quality

1.5: strong service quality

e. Determining Absolute Weight and Normalized Weight Absolute Weight and Normalized Weight are closely related to the effort of fulfilling customer expectations. Absolute Weight $=$ Perception $\mathrm{x}$ Improvement Ratio $\mathrm{x}$ Service Point.

Normalized Weight $=$ Absolute Weight of the related indicator, which is divided by total Absolute Weight. The bigger the score of Normalized Weight, the higher the priority to be improved.

f. Matrix Prioritized Customer Requirement

Overall, from Prioritized Customer Requirement, it can be seen which indicators that need to be prioritized, as shown Table 6.

6) Creating Prioritized Technical Response

Prioritized Technical Response is a planning matrix whose function is to determine the priority level of the corrective actions at How'sTechnical Response.

a. Degree of Difficulty

This matrix contains the degree of difficulty that may hinder the management from fulfilling customer expectations. The Degree of Difficulty scales from 1-5 to reflect the current level of difficulty:

1: Very hard

2: Hard

3: Pretty hard

4: Easy

5: Very easy
Table 7.

Prioritized Technical Response

\begin{tabular}{|l|c|c|c|c|c|}
\hline \multicolumn{1}{|c|}{ Service Attribute } & $\begin{array}{c}\text { Diffi- } \\
\text { culty }\end{array}$ & $\begin{array}{c}\text { Target } \\
\text { Value }\end{array}$ & $\begin{array}{c}\text { Contri } \\
\text { bution }\end{array}$ & $\begin{array}{c}\text { Normal } \\
\text { ized } \\
\text { Weight }\end{array}$ & $\begin{array}{c}\text { Prio- } \\
\text { rity }\end{array}$ \\
\hline $\begin{array}{l}\text { Increase the number of Drafter and } \\
\text { Engineer. }\end{array}$ & 2.00 & 3.00 & 114.22 & 5.13 & 6 \\
\hline $\begin{array}{l}\text { Prepare outsourcing to meet } \\
\text { Engineering demand. }\end{array}$ & 2.00 & 3.00 & 114.22 & 5.13 & 7 \\
\hline $\begin{array}{l}\text { Monitor the progress of Engineering } \\
\text { periodically. }\end{array}$ & 5.00 & 5.00 & 150.94 & 28.25 & 1 \\
\hline $\begin{array}{l}\text { Coordination with users follows } \\
\text { Customer Requirements. }\end{array}$ & 5.00 & 5.00 & 85.99 & 16.09 & 3 \\
\hline \begin{tabular}{l} 
Quality periodic training for Engineers. \\
\hline $\begin{array}{l}\text { Share Knowledge Engineer with } \\
\text { customers. }\end{array}$
\end{tabular} 2.00 & 3.00 & 85.75 & 3.85 & 8 \\
\hline $\begin{array}{l}\text { Benchmark of other Engineering } \\
\text { Service Providers. }\end{array}$ & 1.00 & 1.00 & 24.60 & 0.18 & 10 \\
\hline $\begin{array}{l}\text { Conduct a field survey to provide the } \\
\text { best solution. }\end{array}$ & 4.00 & 4.00 & 48.94 & 5.86 & 5 \\
\hline $\begin{array}{l}\text { Customers are asked to give a PIC to } \\
\text { coordinate. }\end{array}$ & 5.00 & 5.00 & 61.54 & 11.52 & 4 \\
\hline $\begin{array}{l}\text { Communication with customers } \\
\text { periodic. }\end{array}$ & 5.00 & 5.00 & 110.46 & 20.67 & 2 \\
\hline
\end{tabular}

b. Target Value

This Target Value represents the management's ability to implement specific technical responses to improve service quality. Internal FGD is conducted to make sure that each member is in unison about the Target Value.

c. Contribution How and What Matrix

Contribution between How and What Matrices represents the contribution of each item on technical response to fulfill customer expectations on service quality. The following formula can measure contribution: total multiplication of Importance to Customer x correlation between Matrix How and What, which has been agreed upon during FGD.

d. Relative Weight dan Normalized Relative Weight

Relative Weight $=$ absolute multiplication of Degree of Difficulty x Target Value x Contribution. Normalized Relative Weight $=$ Relative Weight divided by total addition of Relative Response. Based on Normalized Relative Weight, the management can determine which Technical Response should be prioritized.

e. Matrix Prioritized Technical Response

Overall, it can be seen from Prioritized Technical Response which actions should be taken first by the management of Design \& Engineering Department, as shown Table 7 .

\section{CONCLUSION AND SUGGESTION}

Based on the study result, the researcher draws the following conclusions:

1. From Gap analysis, it can be claimed that the customers are yet to be satisfied by the company's performance. It is proven from the negative Gap values.

2. The Gaps for each dimension are as follows: Tangible receives -0.352 , Empathy gets -0.393 , Responsiveness receives -0.395 , Reliability gets -0.298 , and Assurance gets -0.343 .

3. According to Importance Performance Analysis (IPA) analysis, there are 5 service attribute on Quadrant A that need improvements. From QFD the priority of service attribute as follow:

a. Employees can complete the design on time. 
The $1^{\text {st }}$ International Conference on Business and Engineering Management (IConBEM 2020)

February $1^{\text {st }} 2020$, Institut Teknologi Sepuluh Nopember, Surabaya, Indonesia

b. Employees can meet the speed and quality of service.

c. Employees can provide solutions to problems.

d. Product Engineering is fulfill following the requirement

e. Speed to coordinate with customers

4. From Quality Function Deployment (QFD), the priority order of the corrective steps for the service problems are as follows:

a. Monitor the progress of Engineering periodically.

b. Communication with customers periodic.

c. Coordination with users follows Customer Requirements.

d. Customers are asked to give a PIC to coordinate.

e. Conduct a field survey to provide the best solution.

f. Increase the number of Drafter and Engineer.

g. Prepare outsourcing to meet Engineering demand.

h. Quality periodic training for Engineers.

i. Share Knowledge Engineer with customers.

j. Benchmark of other Engineering Service Providers.
To improve the service quality, Design \& Engineering Department should take the following suggestions:

1. The management should pay more attention to top priority indicators, so that customer expectations of the service can be improved.

2. Measurement on the service quality is conducted periodically so that the management can keep abreast of customer satisfaction and improve the service quality.

3. Measurement of service quality for the next period, it suggests that in the process of determining Service Attributes, it should involve customers, so that it is more objective and following the customer's perspective.

\section{REFERENCE}

[1] Parasuraman, V. A. Zeithaml, and L. L. Berry, "SERVQUAL: a multiple-item scale for measuring consumer perceptions of service quality," J. Retail., vol. 64, no. 1, pp. 12-40, 1988.

[2] V. Gaspersz, Manajemen Kualitas dalam Industri Jasa. Gramedia Pustaka Utama, 1997. 